\title{
Growth Hormone (GH) Treatment Up-Regulates GH Receptor mRNA Levels in Adipocytes from Patients with GH Deficiency and Prader-Willi Syndrome
}

\author{
ASHRAF KAMEL, VÉRONIQUE MARGERY, GUNNAR NORSTEDT, MARJA THORÉN, \\ ANNE-CHRISTINE LINDGREN, MIKAEL BRÖNNEGÅRD, AND CLAUDE MARCUS \\ Department of Pediatrics, Endocrine Research Unit [A.K., V.M., M.B., C.M.] and Center of \\ Biotechnology, Huddinge Hospital [G.N.], and Departments of Pediatrics [A.C.L.] and Endocrinology and \\ Diabetes [M.T.], Karolinska Hospital, Stockholm, Sweden
}

\begin{abstract}
We have investigated the effect of growth hormone $(\mathrm{GH})$ treatment on GH receptor mRNA expression in five prepubertal children with Prader-Willi syndrome and in eight patients with GH deficiency. An adipose tissue needle biopsy was taken before and after 2-4 mo of GH treatment, and RNA was isolated from adipose tissue and from adipocytes. GH receptor mRNA levels were determined by an RNase protection/solution hybridization assay. To further assess the specificity of the assay for $\mathrm{GH}$ receptor mRNAs, RNA extracted from human adipose tissue was subjected to Northern blot analysis. GH treatment significantly
\end{abstract}

ABSTRACT
The role of $\mathrm{GH}$ in the regulation of growth and metabolism is well documented (1). GH exerts its effects via a membrane bound GH receptor, a $130-\mathrm{kD}$ glycoprotein, that binds $\mathrm{GH}$ with high affinity (2).

Acutely isolated adipocytes possess highly specific receptors for GH (3) and respond to GH by alteration of several metabolic parameters $(4,5)$. GH deficiency results in relative obesity (6). The average size and lipid content of s.c. fat cells in GH-deficient patients is greater than normal (7). Treatment of $\mathrm{GH}$-deficient patients results in decreased average size and lipid content of adipocytes in s.c. fat depots (8).

The effects of $\mathrm{GH}$ administration on the $\mathrm{GH}$ receptor expression are not clear. One factor seems to be the time scale of GH treatment $(9,10)$. Although chronic treatment increases $\mathrm{GH}$ binding in the rat liver, acute adminstration has a downregulatory effect (9). To our knowledge, no data are available

Reccived for rapid publication April 7, 1995; accepted May 29, 1995.

Correspondence: Claude Marcus, M.D., Department of Pediatrics, Endocrine Research Unit, B62, Huddinge University Hospital, Karolinska Institute, S-141 86 Huddinge, Sweden.

Supported by grants from the Swedish Medical Research Council (19X-9941), Karolinska Institute, the Golje Memorial, The Crown Princess Lovisa/Thileman, Swedish Diabetes and Nordic Insulin Foundations, the General Maternity Hospital, and the Pharmacia Company. increased GH receptor mRNA levels in adipose tissue and isolated adipocytes. Our results indicate that GH may have an important role in regulating the GH receptor in humans. (Pediatr Res 38: 418-421, 1995)
GH, growth hormone
hGHR, human GH receptor
PWS, Prader-Willi syndrome
TCA, trichloroacetic acid

Abbreviations

regarding the effects of $\mathrm{GH}$ treatment on $\mathrm{GH}$ receptor expression in man.

The aim of the present study was to evaluate the effects of $\mathrm{GH}$ treatment on $\mathrm{GH}$ receptor mRNA expression in adipose tissue obtained from children with PWS and patients with GH deficiency.

\section{METHODS}

Five prepubertal children with PWS, three children and six adults with $\mathrm{GH}$ deficiency were studied. Children were treated with $0.1 \mathrm{U}$ of $\mathrm{GH}$ per $\mathrm{kg} / \mathrm{d}$. The adults were treated with 0.03 $\mathrm{U}$ of $\mathrm{GH}$ per $\mathrm{Kg} / \mathrm{d}$. An abdominal adipose tissue needle biopsy (1-2 g) was taken before the initiation of treatment and after 2-4 mo of treatment. The last GH injection was given $14 \mathrm{~h}$ before the second biopsy. All biopsies were obtained between 0830 and $0930 \mathrm{~h}$ after an overnight fast. The biopsy was taken after Citanest analgesia in the surrounding area. In three children with PWS, part of the adipose tissue was used to prepare adipocytes. The adipocytes were isolated mainly using Rodbell's method (11). The adipocytes were washed in KrebsRinger phosphate albumin buffer and aggregated material was removed by filtration through a silk cloth. For Northern blots and RNase protection assay, the adipose tissue samples were 
taken from healthy young adults and adipose tissue was pooled from five children 3-6 y of age during inguinal hernia operations. The study was approved by the Ethics Committee of Karolinska Institute.

Preparation of RNA and Northern blot analysis. Total tissue and cellular RNA were extracted as previously described (12). Northern blot analysis was performed, as previously described (13). Briefly, hybridization was carried out for $48 \mathrm{~h}$ at $55^{\circ} \mathrm{C}$ in a solution containing $50 \%$ formamide, $5 \times \mathrm{SSC}, 5$ $\times$ Denhardt's solution, $5 \mathrm{mmol} / \mathrm{L}$ phosphate buffer, $\mathrm{pH} 6.5,5$ $\mathrm{mmol} / \mathrm{L}$ EDTA, $0.1 \% \mathrm{SDS}$, and $200 \mu \mathrm{g}$ of salmon testis DNA, and the addition of $4-6 \times 10^{6} \mathrm{cpm} / \mathrm{mL}^{32} \mathrm{P}$-labeled cRNA GH receptor probe. Oligonucleotide probes $(50 \mathrm{bp})$ were cloned into the BamHI/SalI sites in pGEM+4Z (Promega Biotech). The sequence of these inserts in $\mathrm{pGEM}+4 \mathrm{Z}$ was confirmed by DNA sequencing. For the GH probe, the sequence of the oligonucleotide used corresponded to nucleotides 721-771 in the hGHR gene (14).

Solution hybridization analysis of RNA. For measurement of specific mRNA levels, complementary RNA (cRNA) probes were synthesized in vitro as described before, and radiolabeled with ${ }^{35}$ S-UTP (Amersham, Sweden), using reagents supplied by Promega Biotech (Madison, WI). The solution hybridization assay was carried out as previously described (15). Briefly, the hybridization signal of a sample was compared with a standard curve constructed from incubations with a known amounts of sample. RNA was calculated from the linear part of the respective standard curve. Results are expressed as amol mRNA per $\mu \mathrm{g}$ total RNA calculated from the standard curve and spectrophotometric measurements. Each standard and RNA sample was analyzed in duplicate.

$\gamma$-actin probe was synthesized in vitro and radiolabeled with ${ }^{35} \mathrm{~S}$-UTP as described above (16). The expression of the $\gamma$-actin gene was used as an internal control.

Results are expressed as means \pm SD. Differences between the groups were assessed using the paired $t$ test. $p$ values of less than 0.05 were considered to be significant.

RNase protection assay. The specificity of the solution hybridization method was tested by an RNase protection assay with $100 \mathrm{pg}$ of hGHR-specific sense nucleotide described above and RNA extracts from normal adipose tissue specimens. The RNA extracted was hybridized with labeled sense under conditions identical to those described above. After RNase treatment, extraction with phenol/chloroform and ethanol precipitation, RNA was size-separated by electrophoresis through a denaturating $4 \%$ polyacrylamide gel. Then, the gel was dried and the hybridized probe detected by autoradiography for $24 \mathrm{~h}$. An RNA ladder was used as a marker.

\section{RESULTS}

RNase protection assay and Northern blot analysis. The specificity of cRNA probes used in the present study was evaluated with RNase protection assay. The GH receptor probe corresponds to the intracellular domain of the $\mathrm{GH}$ receptor (13) and it showed no nonspecific hybridization, as indicated by a single discrete band of the RNase-protected products on the gel. As shown in Fig. 1 a RNase protected fragment obtained

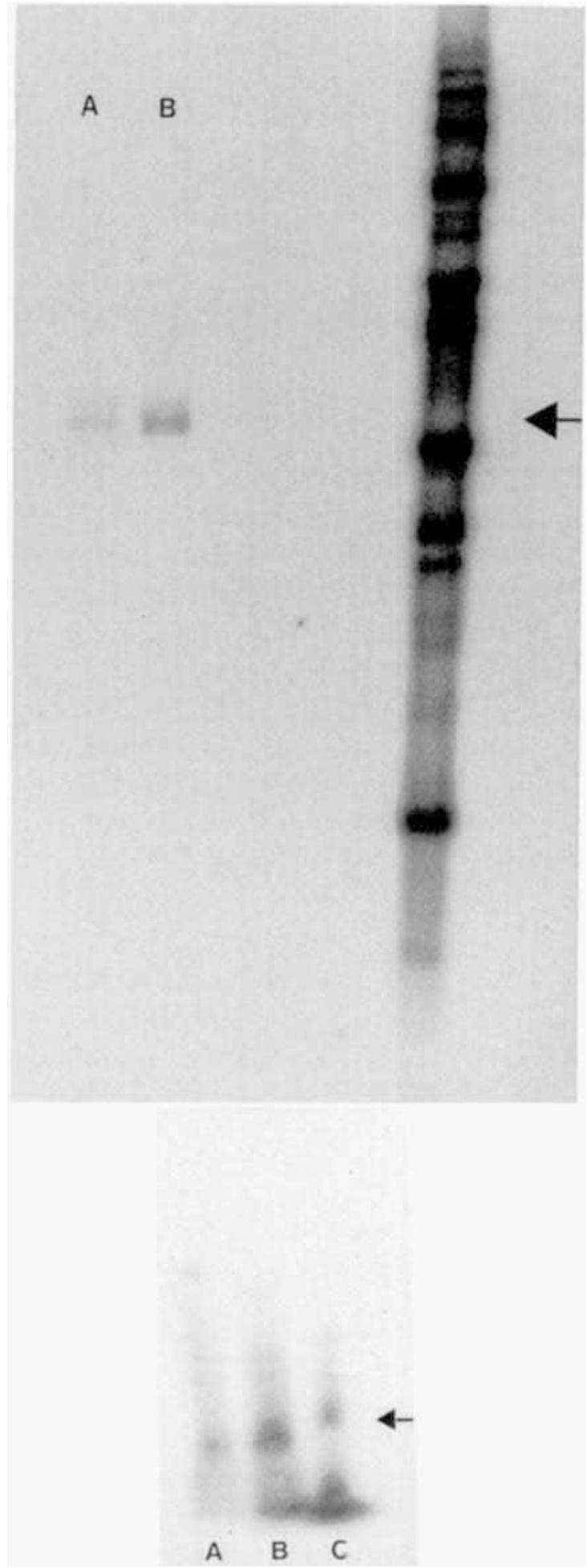

Figure 1. Top panel, total RNA samples isolated from adipose tissue of children $(A)$ and adults $(B)$ were probed for $\mathrm{GH}$ receptor (GHR) using Northern blot analysis. The size $(3.9 \mathrm{~kb})$ of hybridizing species is indicated on the left. Lower panel, RNase protection assay to examine the specificity of cRNA probes used in the present study. (A) Probe hGHR. (B) Synthetic mRNA 10 pg + GHR probe. (C) RNA from a child's adipose tissue $(57 \mu \mathrm{g})+\mathrm{GHR}$ probe. The RNase-protected products on the gel are indicated by arrows.

after hybridization with human adipose tissue RNA had a mobility on SDS gel similar to the 50 nucleotides long $\mathrm{GH}$ receptor-specific probe. To further assess the specificity of the 
assay for GH receptor mRNAs, RNA extracted from human adipose tissue was subjected to Northern blot analysis. The GH receptor probe detected a band of approximately $3.9 \mathrm{~kb}$ in adipose tissue of both children and adults (Fig. 1).

Quantification of $G H$ receptor $m R N A$. The GH receptor mRNA was measured before and during $\mathrm{GH}$ treatment of children with PWS and patients with GH deficiency. To obtain an estimate of the level of $\mathrm{GH}$ receptor mRNA an RNase protection/solution hybridization technique was used. Identical cRNA probe was used as in RNase protection described above but instead of analysis of RNase resistant hybrids on SDS gel the hybrid formation was determined by TCA precipitation and liquid scintillation counting.

The GH receptor mRNA levels in adipose tissue were found to be higher in children with PWS after 2-4 mo of GH treatment than the pretreatment expression levels $(p<0.02)$ (Fig. 2). Furthermore, the GH receptor mRNA levels in adipose tissue from all patients with $\mathrm{GH}$ deficiency were higher after 2-4 mo of $\mathrm{GH}$ treatment than the pretreatment expression levels $(p<0.02)$ (Fig. 3).

In three PWS subjects, GH mRNA levels were measured in adipose tissue and in isolated adipocytes. The mRNA levels were higher in adipose tissue than in adipocytes. However, the same increase in $\mathrm{GH}$ receptor mRNA levels during GH treatment was observed also in the adipocytes (Fig. 2).

The $\gamma$-actin mRNA levels in adipocytes and in adipose tissue of children with PWS and in GH-deficient patients were not affected by $\mathrm{GH}$ treatment (Table 1).

\section{DISCUSSION}

In the present study, the regulatory effect of $\mathrm{GH}$ on $\mathrm{GH}$ receptor mRNA expression in human adipose tissue has been investigated. The presence of the $\mathrm{GH}$ receptor mRNA in human adipose tissue and the specificity of the probe used were confirmed by RNase protection assay and Northern blot, using material from healthy children and adults. A single discrete band of the RNase protected products on SDS gels mediated a specific hybrid formation using RNase protection/solution hybridization assay. Alternatively, using Northern blot, a band of $3.9 \mathrm{~kb}$ was detected which is in accordance with what previously has been demonstrated in other human tissues (13). Two isoforms of hGHR mRNA, one containing exon 3 (encoding an extracellular domain of the receptor), hGHR, and one exclud-
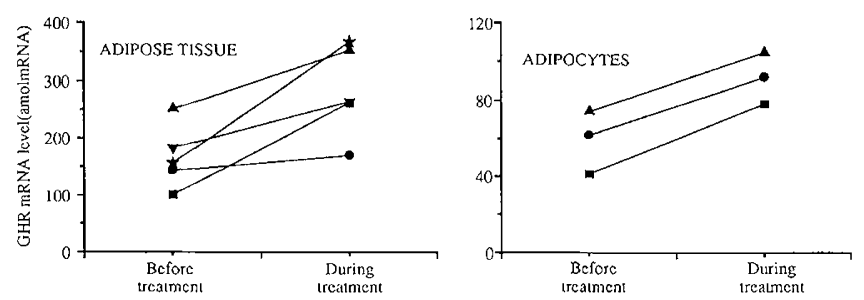

Figure 2. hGHR mRNA levels in adipose tissue and adipocytes from PWS children before and during GH treatment. The mean value of GHR mRNA (expressed as amol RNA/ $\mu \mathrm{g}$ total RNA) in adipose tissue before treatment is $167.4 \pm 55.4$ and $280.3 \pm 76.8$ during $\mathrm{GH}$ treatment $(p<0.02)$. The mean values of hGHR mRNA in adipocytes before and during GH treatment are 59.5 \pm 16.4 and $92 \pm 13.4$, respectively.

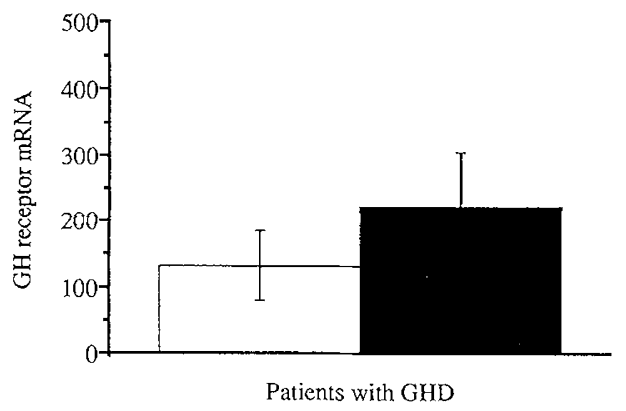

Figure 3. hGHR mRNA levels in adipose tissue from patients with GH deficiency (GHD) before and during GH treatment.The mean value of GHR mRNA (expressed as amol RNA/ $\mu \mathrm{g}$ total RNA) in adipose tissue before and during GH treatment are $132.6 \pm 52.8$ and $223.5 \pm 82.4$, respectively $(p<$ 0.02). $\square$, Before treatment; $\mathbf{m}$, during treatment.

Table 1. $\gamma$-Actin mRNA levels before and during GH treatment.

\begin{tabular}{cccc}
\hline Paticnts & $\mathrm{A}$ & $\mathrm{B}$ & $P$ \\
\hline $\begin{array}{c}\text { Children with PWS, adipose } \\
\text { tissue }(n=5)\end{array}$ & $46.5 \pm 31.3$ & $40.5 \pm 16.7$ & $\mathrm{NS} *$ \\
$\begin{array}{c}\text { Children with PWS, } \\
\text { adipocytes }(n=3)\end{array}$ & $25.9 \pm 5.6$ & $23.7 \pm 9.8$ & $\mathrm{NS}$ \\
$\begin{array}{c}\text { Patients with GHD, adipose } \\
\text { tissue }(n=5)\end{array}$ & $18.4 \pm 12.7$ & $19.8 \pm 10.5$ & $\mathrm{NS}$ \\
\hline
\end{tabular}

Adipose tissue and adipocytes were obtained from children with PWS, and patients with GH deficiency, as described in Methods, before (A), and after 2-4 mo of $\mathrm{GH}$ treatment (B). $\gamma$-Actin mRNA levels are expressed as amol mRNA/ $\mu$ g total RNA.

$* \mathrm{NS}=$ not significant.

ing exon 3, hGHRd3, have been described (14). The GH receptor probe used corresponds to the intracellular domain of the $\mathrm{GH}$ receptor (13). Thus, our results regarding the levels of $\mathrm{GH}$ receptor $\mathrm{mRNA}$ were affected neither by the alternative splicing of the $\mathrm{GH}$ receptor nor by a putative expression of $\mathrm{GH}$ binding protein. GH receptor mRNA expression was significantly higher in adipose tissue of PWS children after 2-4 mo of $\mathrm{GH}$ treatment. The same pattern was observed in $\mathrm{GH}$ deficient patients, the GH receptor mRNA levels being significantly higher in adipose tissue from GH-deficient children and GH-deficient adults during treatment. The GH receptor is expressed in adipocytes and in other cell types in adipose tissue, such as fibroblasts (17). Amounts of adipose tissue sufficient for simultaneous studies of intact adipose tissue and fat cells were obtained from only three subjects with PWS. The $\mathrm{GH}$ receptor mRNA levels were higher in adipose tissue than in isolated adipocytes, which indicate that GH receptor mRNA from other cell types considerably affected the measurements in adipose tissue. However, the relative increase was the same in adipocytes and in the adipose tissue, which indicates that $\mathrm{GH}$ receptors in both adipocytes and stromal cells mRNA are up-regulated by $\mathrm{GH}$.

The expression of the $\gamma$-actin gene is reported to be stable in various cell types and not influenced by hormone levels, such as GH, glucocorticoids or thyroxine (16).

In the present study, the $\gamma$-actin gene mRNA levels in adipocytes and adipose tissue were not affected by GH treatment, indicating a specific increase in GH receptor mRNA. Our results agree with data obtained in rats. In adipocytes from hypophysectomized rats, the specific GH binding was $25 \%$ of 
the binding observed in adipocytes of normal rats. Administration of bovine $\mathrm{GH}$ for $5 \mathrm{~d}$ increased $\mathrm{GH}$ binding approximately 2-fold, compared with controls (18). Furthermore, in vitro studies of isolated fat cells from normal rat show a $75 \%$ increase in $\mathrm{GH}$ receptors after preincubation with $\mathrm{GH}$ (19). In contrast to the prolonged effects of $\mathrm{GH}$, a single injection of $\mathrm{GH}$ greatly reduces both total and free liver $\mathrm{GH}$ receptors in rats $(20)$.

Treatment with GH markedly affects the general metabolism in adults as regards the adipose tissue. This effect of GH on adipocytes is probably direct rather than mediated via IGF-I, because no IGF-I receptors are present in mature adipocytes (21). It has been shown that the dose of GH can be reduced after 1 or 2 mo of treatment, without any negative effects on IGF-I levels or other metabolic parameters (22). This phenomenon may partly be explained by the up-regulation of the $\mathrm{GH}$ receptor that could sensitize tissues to $\mathrm{GH}$.

\section{REFERENCES}

1. Press M 1988 Growth hormone and metabolism. Diabetes Metab Rev 4:391-414

2. Spencer SA, Hammonds RG, Hanzel WJ, Rodriguez H, Waters MJ, Wood WI 1988 Rabbit liver growth hormone receptor and serum binding protein. J Biol Chem 263:7862-7867

3. Herington AC 1982 Identification and charactcrization of growth hormone receptors on isolated adipocytes. J Reccpt Res 2:299-304

4. Grichting G, Levy LK, Goodman HM 1983 Relationship between binding and biological effects of human growth hormonc in rat adipocytes. Endocrinology 113:1111-1120

5. Marcus C, Bolme P, Micha-Johansson G, Margery V, Brönnegård M 1994. Growth hormone increases the lipolytic sensitivity for catecholamines in adipocytes from healthy adults. Life Sci 54:1335-1341

6. Tanner JM, Hughes PRCR, Whitehouse RH 1977 Compartive rapidity of response of hight, limb muscle and limb fat to treatment with human growth hormone in patients with and without growth hormone deficiency. Acta Endocrinol 84:681-696
7. Bonnct F, Vanderschueren-Lodewyckx M, Ekels R, Malvaux P 1974 Subcutaneous adipose tissue and lipids in blood in growth hormone deficiency before and after treatment with human growth hormone. Pediatr Res 8:800-5

8. Brook CGD 1973 Effect of human growth hormone treatment on adipose tissue in children. Arch Dis Child 48:725-8

9. Maiter D, Underwood LE, Maes M, Davenport ML, Ketelslegers JM 1988 Different effects of intermittent and continuous growth hormone $(\mathrm{GH})$ adminstration on serum somatomedin-c/insulin-like growth factor I and liver GH receptors in hypophysectomized rats. Endocrinology 123:1053-1059

10. Bick T, Youdim MBH, Hochberg Z 1989 Adaptation of liver membrane somatogenic and lactogenic growth hormone $(\mathrm{GH})$ binding to the spontancous pulsation of $\mathrm{GH}$ secretion in the male rat. Endocrinology 125:1711-1717

11. Rodbell M 1964 Metabolism of isolated fat cells. Effects of hormones on glucose metabolism and lipolysis. J Biol Chem 239:375-80

12. Chomczynski P, Sacchi N 1987 Single-step method of RNA isolation by acid guanidinium thiocyanate-phenol-chloroform extraction. Anal Biochem 162:156-159

13. Levinovitz V, Husman B, Eriksson LC, Norstedt G, Andersson G 1990 Decreased expression of the growth hormone receptor and growth hormone binding protein in rat liver nodules. Mol Carcinogen 3:157-164

14. Leung DW, Spencer SA, Cachianes G 1987 Growth hormone reccptor and serum binding protein: purification, cloning and expression. Nature 330:537-543

15. Durnam DM, Palmiter RD 1983 A practical approach for quantitating specific mRNAs by solution hybridization. Anal Biocilem 131:385-393

16. Cleveland DW, Lopata MA, Macdonald RJ, Cowan NJ, Rutter WJ, Kirschner MW 1980 Number and evolutionary conservation of $\alpha$ - and $\beta$-tubulin and cytoplasmic $\beta$ and $\gamma$-actin genes using specific cloned cDNA probes. Cell 20:95-105

17. Murphy LJ, Lazarus L 1984 The mouse fibroblasts growth hormone rcceptor: ligand processing and receptor modulation and turnover. Endocrinology 115:1625-1632

18. Gause I, Eden S 1986 Induction of growth hormone $(\mathrm{GH})$ receptors in adipocytes of hypophysectomized rats by GH. Endocrinology 118:119-124

19. Solmon SS, Sibley SD, Cunningham TM 1990 Growth hormone receptors are upregulated in diabetic adipocytes. Endocrinology 127:1544-1546

20. Maiter D, Underwood LE, Maes M, Ketelslegers JM 1990 Acute down-regulation of the somatogenic receptors in rat liver by a single injection of growth hormone. Endocrinology 122:1291-1296

21. Shimisu M, Torti F, Roth RA 1986 Characterization of the insulin and insulin-like growth factor receptors and responsitivity of a fibroblast/adipocyte cell line before and after differntiation. Biochem Biophy Res Commun 137:552-558

22. Bengtsson B, Eden S, Lönn I, Kvist H, Stokland A, Lindstedt G, Bosaeus I, Tölli J, Sjöström L, Isaksson OGP 1993 Treatment of adults with growth hormone (GH) deficiency with recombinant GH. J Clin Endocrinol Metab 76:309-317 